\title{
The potential role of GLUT4 transporters and insulin receptors in the hypoglycaemic activity of Ficus lutea acetone leaf extract
}

\author{
Oyinlola O Olaokun ${ }^{1,3}$, Lyndy J McGaw ${ }^{1}$, Maurice D Awouafack ${ }^{1,4}$, Jacobus N Eloff ${ }^{1}$ and Vinny Naidoo ${ }^{1,2^{*}}$
}

\begin{abstract}
Background: Some Ficus species have been used in traditional African medicine in the treatment of diabetes. The antidiabetic potential of certain species has been confirmed in vivo but the mechanism of activity remains uncertain. The aim was to investigate the hypoglycaemic potential of ten Ficus species focussing on glucose uptake, insulin secretion and the possible mechanism of hypoglycaemic activity.

Methods: The dried and ground leaves of ten Ficus species were extracted with acetone. The dried acetone extract was reconstituted with DMSO to a concentration of $100 \mathrm{mg} / \mathrm{ml}$ which was then serially diluted and used to assay for glucose uptake in muscle, fat and liver cells, and insulin secretion in pancreatic cells.

Results: Only the $F$. lutea extract was able to modulate glucose metabolism. In comparison to insulin in the primary muscle cells, the glucose uptake ability of the extract was $33 \%$ as effective. In the hepatoma cell line, the extract was as effective as metformin in decreasing extracellular glucose concentration by approximately $20 \%$. In the pancreatic insulin secretory assay, the extract was 4 times greater in its secretory activity than commercial glibenclamide. With F. lutea extract significantly increasing glucose uptake in the primary muscle cells, primary fat cells, C2C12 muscle and $\mathrm{H}-4-\|-$-E liver cells, the extract may act by increasing the activity of cell surface glucose transporters. When the 3T3-L1 pre-adipocytes were compared to the primary muscle, primary fat and C2C12 cells, the differences in the former's ability to transport glucose into the cell may be due to the absence of the GLUT4 transporter, which on activation via the insulin receptor decreases extracellular glucose concentrations. Because the pre-adipocytes failed to show any active increase in glucose uptake, the present effect has to be linked to the absence of the GLUT4 transporter.

Conclusion: Only F. lutea possessed substantial in vitro activity related to glucose metabolism. Based on the effect produced in the various cell types, F. lutea also appears to be a partial agonist/antagonist of the insulin cell membrane receptor. While the clinical effectiveness of $F$. lutea is not known, this plant species does possess the ability to modify glucose metabolism.
\end{abstract}

Keywords: African Ficus species, Ficus lutea, Diabetes, Glucose uptake, Insulin secretion

\section{Background}

In many developing countries, herbal medicines are of vital importance in primary health care [1]. This is supported by literature in behavioural and pharmacological sciences with animals and people using a number of different plants species for the control of disease symptoms

\footnotetext{
* Correspondence: vinny.naidoo@up.ac.za

'Phytomedicine Programme, Department of Paraclinical Sciences, University of Pretoria, Private Bag X04, Onderstepoort, Pretoria 0110, South Africa ${ }^{2}$ Biomedical Research Centre, Faculty of Veterinary Sciences, University of Pretoria, Onderstepoort, 0110 Pretoria, South Africa

Full list of author information is available at the end of the article
}

and related illnesses $[2,3]$. One such disorder is diabetes mellitus (DM) which is a chronic disease characterised by prolonged hyperglycaemia, especially post-prandial, in association with the consumption of diets that promote obesity, due to abnormalities in plasma insulin concentrations.

Under normal physiological conditions, insulin is secreted by the $\beta$-cells of the pancreatic Islets of Langerhans in the presence of increased plasma glucose concentrations in a highly controlled manner. This potent anabolic hormone subsequently decreases the plasma glucose 
concentrations to a specific limit, through the suppression of hepatic glucose production, increased macromolecular synthesis of glycogen and triglycerides, and stimulation of peripheral (skeletal muscle and adipose tissue) glucose uptake $[4,5]$. Therefore any defects in the action or production of insulin will lead to physiological hyperglycaemia of DM [5]. Over time, this prolonged chronic hyperglycaemia could result in microvascular and macrovascular damage, causing long term complications such as neuropathy, nephropathy, retinopathy, cardiovascular disease and impaired wound healing that significantly interferes with quality of life and life expectancy [5].

While several types of DM can occur, type I and type II predominate. In type I diabetes, or insulin dependent DM, the body has little or no insulin secretory capacity and depends on exogenous insulin to prevent metabolic disorders and death. In type II diabetes, a non-insulin dependent DM, the body retains some endogenous insulin secretory capability; however, insulin levels are low relative to blood glucose levels and/or there is a measure of insulin resistance. Type II diabetes is the most prevalent form of the disease, accounting for $90-95 \%$ of cases globally [6,7].

While conventional treatments such as sulfonylureas, metformin and thiazolidinedones are effective, they have several limitations, including adverse side effects, secondary failure or the inability to halt further loss of insulin secretory capacity [8]. Newer and cheaper medications are therefore needed. One solution is to use herbal remedies, which appear to be widely used with relatively few documented side effects [9].

Several species of the genus Ficus (family Moraceae) are used traditionally in the management of diabetes [10,11]: Ficus benghalensis L. [12], Ficus carica L. [13], Ficus racemosa L. [14], Ficus hispida L. [15], Ficus microcarpa L.f. [16], Ficus religiosa L. [17], Ficus thonningii Blume [18], Ficus glumosa Del. [19], Ficus arnottiana Miq. [20], Ficus glomerata Roxb. [21], F. sycomorus L. [22] and F. deltoidea Jack [23]. Despite their widespread use, the activity and possible mechanism of activity of Ficus species is yet to be determined. The aim of this study was therefore to investigate the mechanisms of the antidiabetic activity, if any, of ten selected Ficus species.

\section{Methods}

\section{Reagents and chemicals}

Roswell Park Memorial Institute Medium 1640 (RPMI 1640), foetal calf serum (FCS)/ foetal bovine serum (FBS), bovine calf serum (BCS), glutamine, trypsin-EDTA, phosphate buffered saline (PBS), sodium pyruvate, Hanks balanced salt solution (HBSS), glucose oxidase kit (GAGO 20), bovine serum albumin (BSA), Minimum Essential Medium (MEM), Dulbecco's MEM (DMEM), 3-(4,5-dimethylthiazol2-yl)-2,5-diphenyl tetrazolium bromide (MTT), 2-[4-(2- hydroxyethyl)piperazin-1-yl]-ethanesulfonic acid (HEPES), collagenase (type 11), penicillin/streptomycin, glibenclamide and D-glucose were purchased from Sigma (South Africa). Gentamicin (Virbac), insulin (Sanofi Aventis), Trypan blue (Fluka), doxorubicin (Pfizer) and Insulin (Rat) ELISA kit (DRG Instruments $\mathrm{GmbH}$, Germany Frauenbergst). Sodium hydrogen carbonate $\left(\mathrm{NaHCO}_{3}\right)$, potassium chloride $(\mathrm{KCl})$, sodium hydrogen phosphate $\left(\mathrm{NaH}_{2} \mathrm{PO}_{4}\right)$, calcium chloride $\left(\mathrm{CaCl}_{2}\right)$, magnesium sulphate $\left(\mathrm{MgSO}_{4}\right)$, sodium chloride $(\mathrm{NaCl})$, magnesium chloride $\left(\mathrm{MgCl}_{2}\right)$ potassium hydrogen phosphate $\left(\mathrm{KH}_{2} \mathrm{PO}_{4}\right)$, dimethyl sulphoxide (DMSO), acetone, methanol, hydrogen chloride $(\mathrm{HCl})$, sulphuric acid $\left(\mathrm{H}_{2} \mathrm{SO}_{4}\right)$ and Whatman No. 1 filter paper were purchased from Merck (South Africa). The absorbance measurements were read using a microtitre plate reader (VERSAmax, Molecular Devices, Labotec).

\section{Cell lines and primary cell cultures}

C2C12 mouse muscle myoblast (CRL-1772), 3T3-L1 mouse pre-adipocytes fibroblast (CL-173), H411E rat hepatoma (CRL-1548), and RIN-m5F rat insulinoma (CRL-11065) were purchased from American Type Culture Collection (ATCC) (Manassas, VA). The primary abdominal muscle and epididymal fat pad were collected opportunistically post-mortem from other animal studies, approved by the Animal Use and Care Committee (AUCC) of the University of Pretoria.

\section{Plant material}

The leaves of the ten Ficus species were collected at the Manie van der Schijff Botanical Garden (University of Pretoria), South Africa in February 2009. The names of the plant species are Ficus capreifolia Delile, Ficus cordata Thunb., Ficus craterostoma Warb. ex Mildbr. \& Burret, Ficus glumosa Delile, Ficus lutea Vahl, Ficus natalensis Hochst., Ficus polita Vahl, Ficus religiosa L., Ficus sycomorus L., and Ficus thonningii Blume. Voucher specimens are placed in the HGWJ Schweickerdt Herbarium of the same institution (for voucher numbers see Olaokun et al. [24]). Leaf material was dried at room temperature, milled to a fine powder (Macsalab mill, Eriez ${ }^{\bullet}$ Bramley) and stored at room temperature in the dark until extracted [25]. Powdered material $(2 \mathrm{~g})$ was extracted with acetone $(20 \mathrm{ml}$, Merck technical grade) using a platform shaker (Labotec) at room temperature for $30 \mathrm{~min}$ [26]. Extracts were centrifuged at $500 \times \mathrm{g}$ for $5 \mathrm{~min}$ (Hettich centrifuge) filtered three times (Whatman No. 1 filter paper), prior to drying at room temperature under a stream of cold air. Crude extracts were dissolved in DMSO (100\%) to produce stock solutions of $100 \mathrm{mg} / \mathrm{ml}$ prior to some of the assays.

\section{Isolation of compounds}

Dried extract $(74 \mathrm{~g})$ re-dissolved in $50 \%$ acetone in water, was successively and exhaustively partitioned 
(by liquid-liquid extraction) with hexane, chloroform/ dichloromethane, ethyl acetate and n-butanol (in order of increasing polarity) [27]. With the F. lutea activity related to glucose utilisation residing in the ethyl acetate fraction, $12 \mathrm{~g}$ ethyl acetate fraction was subjected to silica gel column chromatography eluting with increasing polarity of n-hexane (n-hex), ethyl acetate (EtOAc) and methanol $(\mathrm{MeOH})$ mixtures to afford 115 fractions of $500 \mathrm{~mL}$ each. Fractions 46-52 eluted with n-hex: EtOAc (70:30) were also subjected to similar silica gel column chromatography as fractions 10-30 followed by preparative TLC to afford a compound of about $21 \mathrm{mg}$.

\section{General experimental procedures}

Column chromatography was performed on MN silica gel $60(0.063-0.2 \mathrm{~mm} / 70-230)$ mesh. Pre-coated plates of TLC silica gel $60 \mathrm{~F}_{254}$ (Merck, Germany) were used for monitoring fractions and spots were detected with UV light (254 and $365 \mathrm{~nm}$ ) and then sprayed with $3 \%$ $\mathrm{H}_{2} \mathrm{SO}_{4}$ followed by heating to $110^{\circ} \mathrm{C}$. The structures of compounds were elucidated using ${ }^{1} \mathrm{H}$ and ${ }^{13} \mathrm{C}$ nuclear magnetic resonance (NMR) with spectra recorded using a Bruker spectrometer at $500 \mathrm{MHz}$ and Variant spectrometer at $400 \mathrm{MHz}$. Chemical shifts $(\delta)$ were quoted in parts per million (ppm) from internal standard tetramethylsilane (TMS).

\section{Glucose uptake in established cell lines Complete growth medium}

Frozen vials of cells were revived according to ATCC guidelines. The $\mathrm{C} 2 \mathrm{C} 12$ myocytes were maintained in DMEM culture medium supplemented with $10 \%$ foetal bovine serum (FBS) and $4 \mathrm{mM}$ glutamine. The 3T3-L1 pre-adipocytes were maintained in DMEM culture medium supplemented with $10 \%$ bovine calf serum (BCS) and $4 \mathrm{mM}$ glutamine. The H-4-11-E hepatoma cells were maintained in MEM culture medium supplemented with $10 \% \mathrm{FBS}$ and $2 \mathrm{mM}$ glutamine, while the RIN-m5F insulinoma cells were maintained in RPMI1640 with $2 \mathrm{mM}$ glutamine supplemented with $10 \%$ FBS, $10 \mathrm{mM}$ HEPES and $1 \mathrm{mM}$ sodium pyruvate.

Glucose uptake was determined by the methods of $[28,29]$. The C2C12 myocytes (25 000 cells/ml in DMEM supplemented with $10 \% \mathrm{FBS}$ ), the 3T3-L1 pre-adipocytes (30 000 cells $/ \mathrm{ml}$ in DMEM supplemented with 10\% BCS) and the H-4-11-E hepatoma cells (30 000 cells/ml in MEM supplemented with $10 \% \mathrm{FBS})$ seeded $(200 \mu \mathrm{l})$ into wells of 96-well microtitre plates. After incubation at $37^{\circ} \mathrm{C}$ in a $5 \%$ $\mathrm{CO}_{2}$ incubator for 4 days ( $\mathrm{C} 2 \mathrm{C} 12$ and 3T3-L1) and 2 days (H-4-11-E), the medium in each of the wells was removed and replaced with $100 \mu \mathrm{l}$ of DMEM supplemented with $0.25 \%$ BSA containing plant extracts at concentrations of $15,31,63,125,250$ and $500 \mu \mathrm{g} / \mathrm{ml}$. The cells were subsequently incubated at $37^{\circ} \mathrm{C}$ in a $5 \% \mathrm{CO}_{2}$ incubator for $1 \mathrm{~h}$
(C2C12), 11/2h (3T3-L1) and $3 \mathrm{~h}(\mathrm{H}-4-11-\mathrm{E})$ with the various treatments. Insulin $(0.1-100 \mu \mathrm{M})$ served as the positive control for the $\mathrm{C} 2 \mathrm{C} 12$ and 3T3-L1 cells and was incubated for $1 \mathrm{~h}$ and $1 \frac{1}{2} \mathrm{~h}$ respectively while metformin and insulin prepared in growth medium $(0.1-100 \mu \mathrm{M})$ were the positive controls for H-4-11-E cells. Cells treated with metformin were incubated for $24 \mathrm{~h}$. The solvent control was $0.5 \%$ DMSO. Glucose concentration in the medium was determined by the glucose oxidase method (Sigma GAGO 20 test kit) according to instructions. All experiments were carried out in triplicate and repeated on three separate occasions $(n=9)$. When a plant extract tended to enhance glucose uptake, the effect was re-tested in the presence of insulin at $1 \mu \mathrm{M}$ and $10 \mu \mathrm{M}$.

\section{Glucose uptake in primary cell cultures Rat abdominal skeletal muscle}

Rat abdominal muscle tissue was prepared using the modified method of Gray and Flatt [30], from 8 week old male Sprague-Dawley rats $(\mathrm{n}=12)(170-250 \mathrm{~g})$ from the University of Pretoria Biomedical Research Centre. Excised abdominal muscle was washed twice in $10 \mathrm{ml}$ PBS, sectioned into 10-20 g pieces and transferred into $20 \mathrm{ml}$ Krebs-Ringer bicarbonate-bovine serum albumin (KRB-BSA) pH 7.0 (consisting of $118 \mathrm{mM} \mathrm{NaCl}$, $25 \mathrm{mM} \mathrm{NaHCO}, 1.18 \mathrm{mM} \mathrm{MgSO} 4,1.25 \mathrm{mM} \mathrm{CaCl}_{2}$, $5 \mathrm{mM} \mathrm{KCl}, 1.17 \mathrm{mM} \mathrm{KH}_{2} \mathrm{PO}_{4}$ and $0.2 \% \mathrm{BSA}$ ) before final gentle agitation at $37^{\circ} \mathrm{C}$ for $20 \mathrm{~min}$ in carbogen. Each muscle square was then transferred into micro-titre wells containing $450 \mu \mathrm{l}$ KRB-BSA supplemented with $2 \mathrm{mM}$ sodium pyruvate, $1 \mathrm{mM}$ glucose and $50 \mu \mathrm{l}$ of test substance $(n=9)$ prior to incubation at $30^{\circ} \mathrm{C}$ for $45 \mathrm{~min}$. Final concentrations were plant extracts $(12.5-200 \mu \mathrm{g} / \mathrm{ml})$, insulin $(0.1-100 \mu \mathrm{M})$ and DMSO (1\%). Glucose was quantified as above and change in glucose concentration was calculated using the following formula:

$\%$ glucose uptake
$=100 \times \frac{\text { Absorbance control (untreated cells)-Absorbance sample (treated cells) }}{\text { Absorbance control (untreated cells) }}$

\section{Rat epididymal adipose cells}

Isolated adipocytes were obtained using the method of Rodbell [31] as modified by Martz et al. [32]. The epididymal fat pads (same rats as above) were rinsed in PBS and finely minced and agitated at $37^{\circ} \mathrm{C}$ for $1 \mathrm{~h}$ in DMEM containing $25 \mathrm{mM}$ HEPES, collagenase type $11(1 \mathrm{mg} / \mathrm{ml})$, and BSA $(40 \mathrm{mg} / \mathrm{ml})$. Cells were isolated by first filtration (1000 $\mu \mathrm{m}$ nylon mesh) and subsequent centrifugation at $400 \times \mathrm{g}$ for $1 \mathrm{~min}$. The bottom layer was finally aspirated to obtain a cell layer. Isolated cells were washed three times in HEPES buffered Krebs-Ringer solution, $\mathrm{pH}$ 7.0, 
consisting of $20 \mathrm{mM}$ HEPES, $120 \mathrm{mM} \mathrm{NaCl}, 1.2 \mathrm{mM}$ $\mathrm{MgSO}_{4}, 2.0 \mathrm{mM} \mathrm{CaCl}, 2.5 \mathrm{mM} \mathrm{KCl}, 1 \mathrm{mM} \mathrm{NaH} \mathrm{PO}_{4}$, $1 \mathrm{mM}$ sodium pyruvate and $1 \% \mathrm{BSA}$, penicillin (20 units $/ \mathrm{ml}$ ) and streptomycin $(20 \mathrm{mg} / \mathrm{ml}))$ prior to final suspension in the same buffer. Adipocyte number and viability were determined by trypan blue exclusion. For assays, primary adipocytes were suspended in medium supplemented with $1 \mathrm{mM}$ D-glucose, in a shaking water bath at $37^{\circ} \mathrm{C}$ for $20 \mathrm{~min}$. Cell suspension $(200 \mu \mathrm{l})$ was plated at a density of $1.0 \times 10^{3}$ cells/well in a 96-well microtitre plate with $50 \mu \mathrm{l}$ of plant extracts $(n=9)$, to yield final concentrations of plant extract $(12.5-200 \mu \mathrm{g} / \mathrm{ml})$, insulin $(0.1,1,10,100 \mu \mathrm{M})$ and DMSO (1\%). Plates were incubated at $37^{\circ} \mathrm{C}$ in a $5 \% \mathrm{CO}_{2}$ incubator for $1 \mathrm{~h}$, prior to glucose quantification as above.

\section{Insulin secretion assay}

Insulin secretion by RIN-m5F cells was determined by the method of Persaud et al. [33]. The RIN-m5F insulinoma cells (100 000 cells $/ \mathrm{ml})$ were suspended in RPMI-1640 supplemented with 10\% FBS, $10 \mathrm{mM}$ HEPES and $1 \mathrm{mM}$ sodium pyruvate $(200 \mu \mathrm{l})$ into 96 well plates. Cells were incubated at $37^{\circ} \mathrm{C}$ in a $5 \% \mathrm{CO}_{2}$ incubator for $48 \mathrm{~h}$, after which the medium was exchanged for a glucose-free Krebs-Ringer bicarbonate (KRB) buffer (135 mM NaCl, $3.6 \mathrm{mM} \mathrm{KCl,} 5 \mathrm{mM} \mathrm{NaHCO}, 0.5 \mathrm{mM}$ $\mathrm{NaH}_{2} \mathrm{PO}_{4}, 0.5 \mathrm{mM} \mathrm{MgCl}$ and $1.5 \mathrm{mM} \mathrm{CaCl}_{2}$ ) pH 7.4 supplemented with $1 \mathrm{mg} / \mathrm{ml}$ BSA and $10 \mathrm{mM}$ HEPES for a further $2 \mathrm{~h}$ of incubation. The medium was subsequently replaced with $100 \mu \mathrm{l}$ of glucose-free KRB containing plant extract $(62.5-500 \mu \mathrm{g} / \mathrm{ml})$, glibenclamide $(0.1-10 \mu \mathrm{M})$ or plain medium, and incubated at $37^{\circ} \mathrm{C}$ in a $5 \% \mathrm{CO}_{2}$ for $1 \mathrm{~h}$. The insulin content of supernatants $(n=9)$ were determined using DRG diagnostic Insulin (Rat) ELISA kit, and the following formula:

$\%$ Insulin secreted

$$
\begin{aligned}
= & {\left[\left(\frac{\text { Absorbance sample }(\text { treated cells })}{A \text { bsorbance control }(\text { untreated cells })}\right) \times 100\right] } \\
& -100
\end{aligned}
$$

To determine toxicity, cells were exposed to the extract or pure compound for $48 \mathrm{~h}$ of exposure prior to 3-(4,5-dimethylthiazol-2-yl)-2,5-diphenyl tetrazolium bromide (MTT) assay [34]. In short, once confluent the wells were rinsed with PBS $(200 \mu \mathrm{l})$ and fresh medium $(200 \mu \mathrm{l})$ containing $30 \mu \mathrm{l}$ of MTT $(5 \mathrm{mg} / \mathrm{ml}$ in PBS) was added to each well and further incubated for $4 \mathrm{~h}$. Subsequently, the medium was aspirated without disturbing the formazan crystals and replaced with $50 \mu \mathrm{l}$ of DMSO. The absorbance of the coloured formazan was measured at $570 \mathrm{~nm}$ after gentle shaking using a microplate reader (VERSAmax). The percentage cell viability was calculated as the absorbance of the treated well divided by the absorbance of the solvent control well. The correlation between percentage cell viability and percentage insulin secretion was carried out.

\section{Statistical analyses}

All experiments were performed in triplicate and repeated on three different occasions to yield nine dose-response curves. Statistical analyses of glucose uptake assays and insulin secretion were done by one-way analysis of variance (ANOVA) and considered to be significantly different at $p<0.05$. When significance was found, location of significance was determined by Bonferroni and Tukey HSD multiple comparison post hoc tests. The correlation coefficients $\left(R^{2}\right)$ between viability of RIN-m5F pancreatic $\beta$-cells and insulin secretion were also calculated. All analyses were undertaken in SPSS 20 (IBM). Data are presented as the mean \pm standard error of mean (S.E.M.).

\section{Results}

\section{Glucose uptake activity in $\mathrm{C} 2 \mathrm{C} 12$ muscle cells}

The effect of the acetone leaf extracts of the ten Ficus species on glucose uptake in $\mathrm{C} 2 \mathrm{C} 12$ muscle cells is presented in Figure 1A. Only F. lutea extract significantly $(p<0.001)$ enhanced glucose uptake in C2C12 muscle cells of $9.9 \pm 2.7 \mu \mathrm{g} / \mathrm{ml}(14.9 \pm 2.3 \%)$ at $500 \mu \mathrm{g} / \mathrm{ml}$, with no activity at concentrations below $63 \mu \mathrm{g} / \mathrm{ml}$. DMSO (solvent control) had a weak activity of $1.2 \pm 0.2 \mu \mathrm{g} / \mathrm{ml}$ $(1.8 \pm 0.3 \%)$, but insulin significantly $(p<0.001)$ enhanced glucose uptake of $12.7 \pm 3.7 \mu \mathrm{g} / \mathrm{ml}(19.1 \pm 3.7 \%)$ at a $10 \mu \mathrm{M}$. With $F$. lutea extract being partially effective on C2C12 cell glucose uptake, the effect of the F. lutea in the presence of insulin $(1 \mu \mathrm{M}$ and $10 \mu \mathrm{M})$ was evaluated (Figure 1B). Insulin at the two concentrations, significantly $(p<0.001)$ increased the glucose uptake in the C2C12 muscle cells. In the presence $1 \mu \mathrm{M}$ and $10 \mu \mathrm{M}$ insulin the $F$. lutea extract significantly $(p<0.05)$ increased the glucose uptake in the $\mathrm{C} 2 \mathrm{C} 12$ muscle cells $[13.0 \pm 0.6 \mu \mathrm{g} / \mathrm{ml}$ $(19.5 \pm 0.7 \%)$ and $13.9 \pm 1.4 \mu \mathrm{g} / \mathrm{ml}(20.8 \pm 1.6 \%)$ respectively] at the highest concentration of $500 \mu \mathrm{g} / \mathrm{ml}$ compared to the $F$. lutea extract alone. A marginal increase was seen for the lower doses of F. lutea with insulin present in comparison to its absence. Surprisingly, insulin at both the tested concentrations did not have the maximum effect of $9.12 \pm 0.23 \mu \mathrm{g} / \mathrm{ml}(13.7 \pm 0.36 \%)$ and $12.7 \pm 3.1 \mu \mathrm{g} / \mathrm{ml}$ $(19.1 \pm 3.7 \%)$, when combined with the lower concentrations of the F. lutea extract.

\section{Extracellular glucose concentration of $\mathrm{H}-4-11-\mathrm{E}$ liver cells}

The effect of the acetone extracts of the ten Ficus species on extracellular glucose concentration of H-4-II-E liver cells is presented in Figure 2A. Only F. lutea extract significantly $(p<001)$ decreased extracellular glucose concentration $[12.9 \pm 0.6 \mu \mathrm{g} / \mathrm{ml}(19.3 \pm 0.6 \%)]$ at the highest concentration $(500 \mu \mathrm{g} / \mathrm{ml})$ into $\mathrm{H}-4$-II-E liver cells. The 


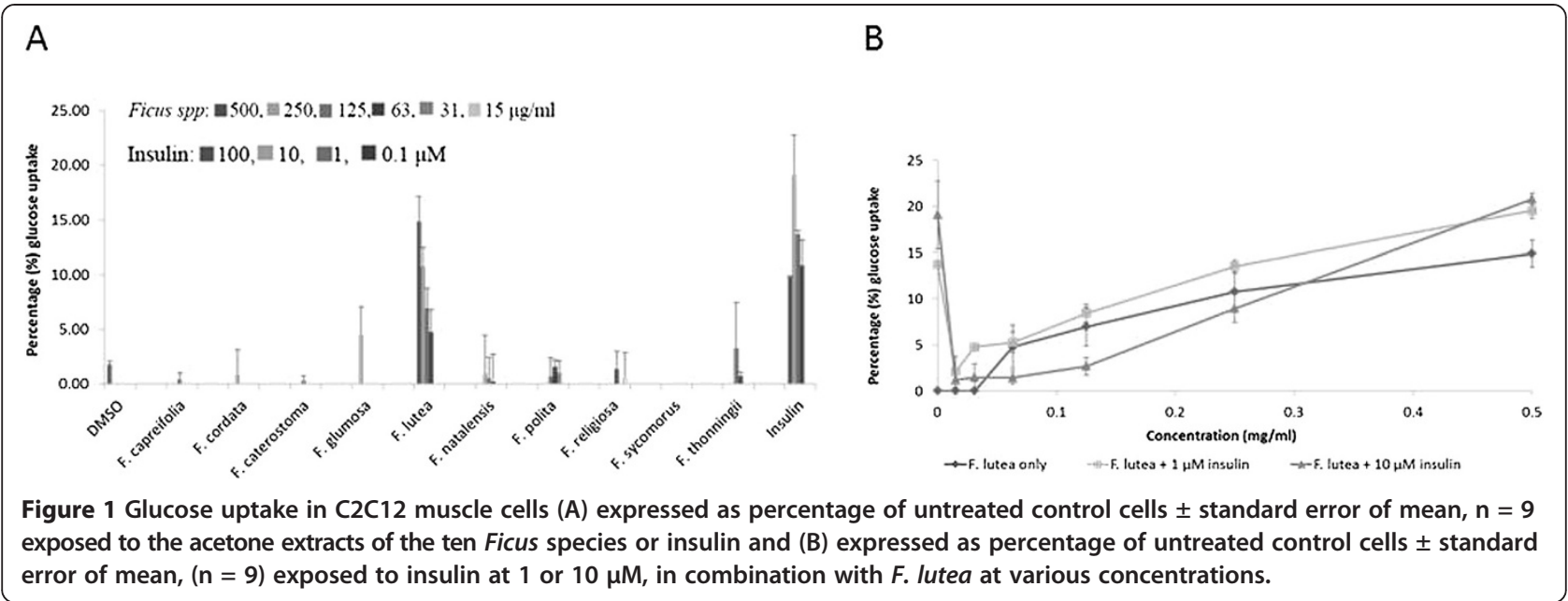

solvent control (DMSO) had minimal glucose uptake activity of $2.3 \pm 1.2 \mu \mathrm{g} / \mathrm{ml}(3.4 \pm 1.8 \%)$, while metformin and insulin significantly $(p<0.001)$ decreased extracellular glucose concentrations with the greatest decrease being $12.0 \pm 0.4 \mu \mathrm{g} / \mathrm{ml}(18.1 \pm 0.6 \%)$ and $11.5 \pm 0.1 \mu \mathrm{g} / \mathrm{ml}$ $(17.3 \pm 0.1 \%)$ respectively. With only the $F$. lutea extract being effective, the activity of the F. lutea extract in the presence of insulin was investigated (Figure 2B). Ficus lutea, at the highest concentration $(500 \mu \mathrm{g} / \mathrm{ml})$ in the presence of insulin (concentrations of $1 \mu \mathrm{M}$ and $10 \mu \mathrm{M}$, decreased the extracellular glucose concentrations of H-4-II-E liver cells significantly $(p<0.05)[14.5 \pm 1.2 \mu \mathrm{g} / \mathrm{ml}(21.8 \pm 1.6 \%)]$ and $(p<0.001)[16.4 \pm 1.3 \mu \mathrm{g} / \mathrm{ml}(24.6 \pm 1.7 \%)]$ at both insulin concentrations compared to the extract and insulin alone. A marginal decrease was seen for the lower doses of F. lutea with insulin present in comparison to its absence. As above, insulin at both the tested concentrations did not have its maximum effect of $10.7 \pm 0.3 \mu \mathrm{g} / \mathrm{ml}$ ) $16.0 \pm 0.5 \%$ and $11.5 \pm 0.1 \mu \mathrm{g} / \mathrm{ml}(17.3 \pm 0.1 \%)$, respectively when combined with the $F$. lutea extract.

\section{Glucose uptake in 3T3-L1 pre-adipocytes}

No extract of any of the Ficus species enhanced glucose uptake in the 3T3-L1 pre-adipocytes even at the highest concentration of $500 \mu \mathrm{g} / \mathrm{ml}$. Insulin, the positive control, significantly $(p<0.001)$ enhanced glucose uptake in $3 \mathrm{~T} 3-\mathrm{L} 1$ pre-adipocytes with the highest glucose uptake of $15.8 \pm 1.8 \mu \mathrm{g} / \mathrm{ml}(23.7 \pm 2.1 \%)$ at the concentration $10 \mu \mathrm{M}$ while the uptake in the DMSO treated cells was $4.3 \pm 0.9 \mu \mathrm{g} / \mathrm{ml}(6.5 \pm 1.1 \%)$ (Figure 3 ).

\section{Glucose uptake activity in primary cell culture}

The effect of the acetone extracts of the ten Ficus species on glucose uptake in primary rat abdominal muscle cultures at $1 \mathrm{mM}$ glucose is presented in Figure 4. Ficus lutea extract at the concentration of $200 \mu \mathrm{g} / \mathrm{ml}$ induced the

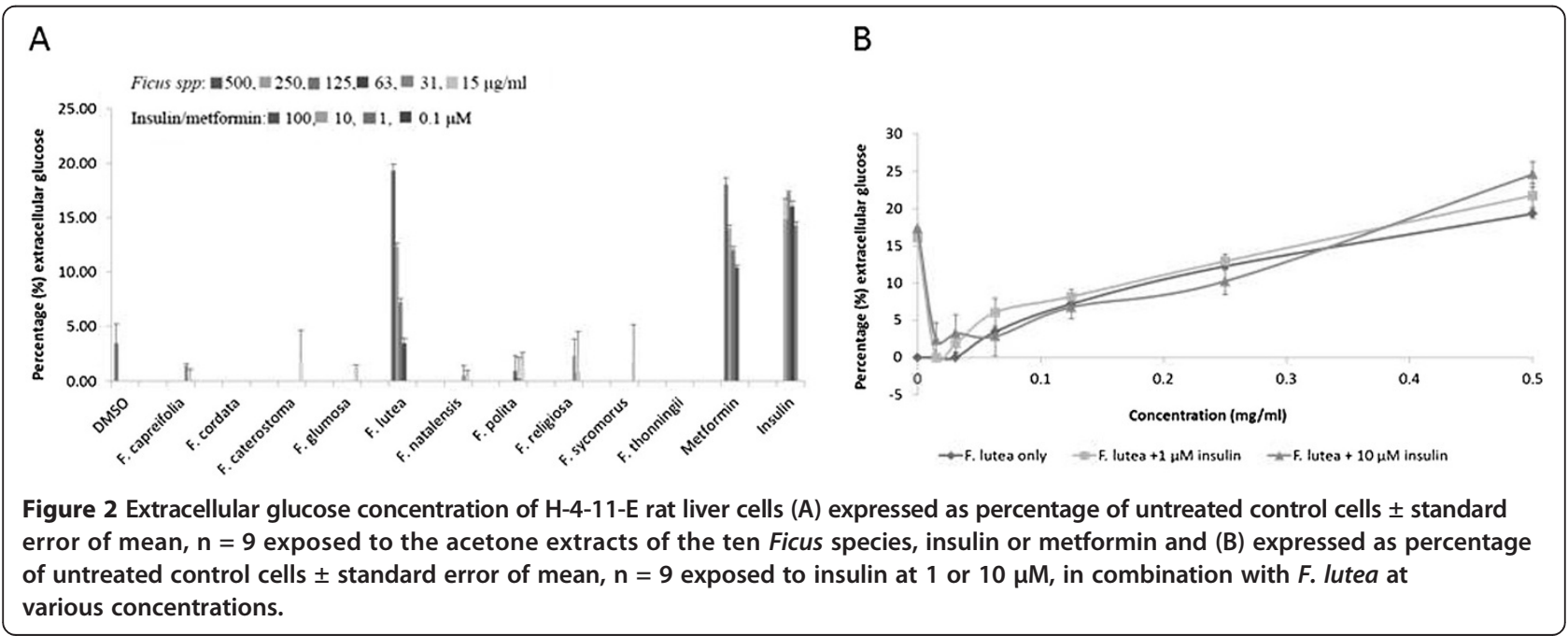




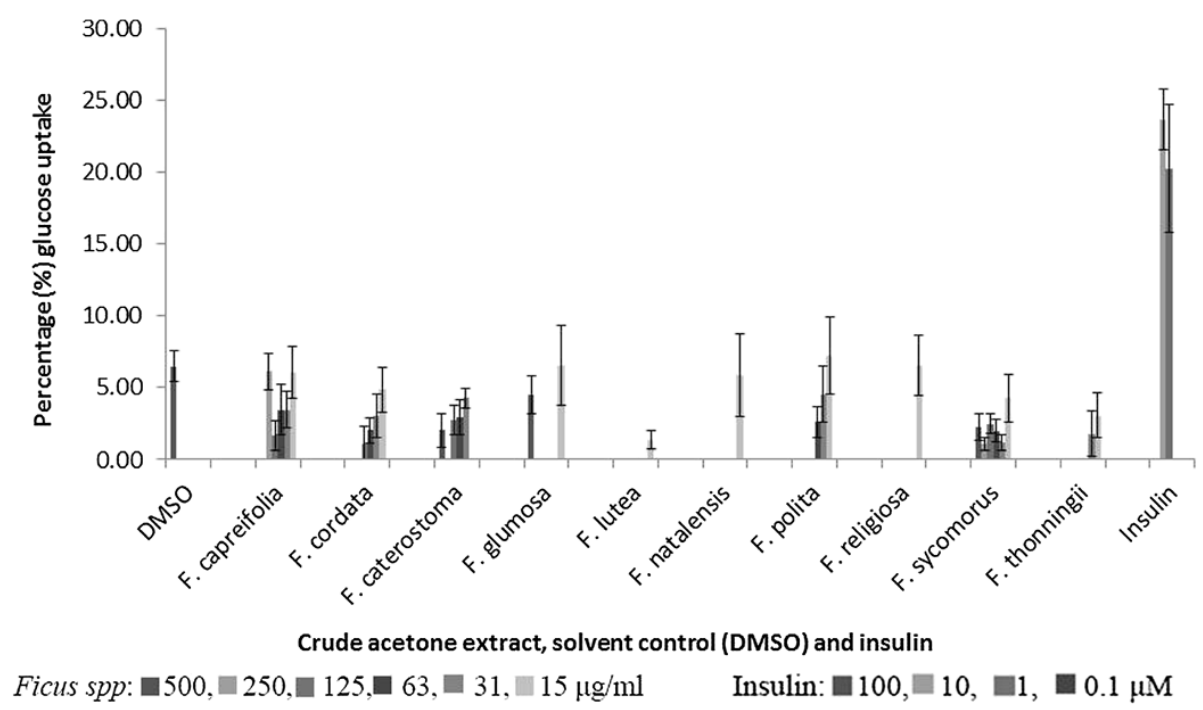

Figure 3 Glucose uptake in 3T3-L1 pre-adipocytes (expressed as percentage of untreated control cells \pm standard error of mean, $n=9$ ) exposed to the acetone extracts of the ten Ficus species or insulin.

highest $[7.2 \pm 1.3 \mu \mathrm{g} / \mathrm{ml}(10.8 \pm 1.8 \%)]$ glucose uptake into muscle cultures but was not significantly different $(p<0.05)$ from glucose uptake induced by the extracts of F. thonningii $[5.4 \pm 0.4 \mu \mathrm{g} / \mathrm{ml}(8.1 \pm 0.7 \%)], F$. natalensis $[4.7 \pm 6.5 \mu \mathrm{g} / \mathrm{ml}(7.0 \pm 7.7 \%)]$ and F. glumosa $[3.9 \pm 2.4 \mu \mathrm{g} / \mathrm{ml}$ $(5.9 \pm 2.7 \%)]$ at the same concentration and in comparison to the DMSO solvent control $[3.8 \pm 0.9 \mu \mathrm{g} / \mathrm{ml}(5.7 \pm 1.4 \%)]$. This uptake was only $33 \%$ of that induced by insulin $[23.8 \pm 1.1 \mu \mathrm{g} / \mathrm{ml}(35.7 \pm 1.0 \%)]$ at $100 \mu \mathrm{M}$. The effect of the acetone extracts of the ten Ficus species on glucose uptake in rat epididymal fat cells at $1 \mathrm{mM}$ glucose is presented in Figure 5. Only the extracts of F. lutea and $F$. glumosa significantly $(p<0.001)$ induced glucose uptake in the primary fat cell cultures of $21.3 \pm 6.2 \mu \mathrm{g} / \mathrm{ml}$ $(32.0 \pm 8.4 \%)$ and $21.0 \pm 4.8 \mu \mathrm{g} / \mathrm{ml}(31.6 \pm 5.7 \%)$ respectively at $200 \mu \mathrm{g} / \mathrm{ml}$. As was the case for the abdominal muscle, the solvent control (DMSO) also had some activity
$[13.7 \pm 3.9 \mu \mathrm{g} / \mathrm{ml}(20.6 \pm 4.2 \%)]$. Insulin was most effective with uptake of $54.8 \pm 1.1 \mu \mathrm{g} / \mathrm{ml}(82.2 \pm 2.0 \%)$ at $100 \mu \mathrm{M}$.

\section{Insulin secretion in RIN-m5F pancreatic cells}

With only $F$. lutea extract having a good activity in the above assays, the acetone extract of $F$. lutea was also evaluated for its insulin secretory activity in RINm5F pancreatic $\beta$-cells (Figure 6A). A concentration dependent increase in insulin secretion was present for $F$. lutea, with significant $(p<0.001)$ increase from $6.3 \pm 0.2 \mu \mathrm{g} / \mathrm{L}$ to $11.1 \pm 0.3 \mu \mathrm{g} / \mathrm{L}(26.4 \pm 6.4 \%$ to $120.8 \pm$ $13.7 \%$ ) from concentrations of $62.5 \mu \mathrm{g} / \mathrm{ml}$ to $500 \mu \mathrm{g} / \mathrm{ml}$. Glibenclamide also significantly $(p<0.001)$ increased insulin secretion in a concentration dependent manner. An inverse linear correlation was present between cell viability and insulin release for the F. lutea extract (Figure 6B).

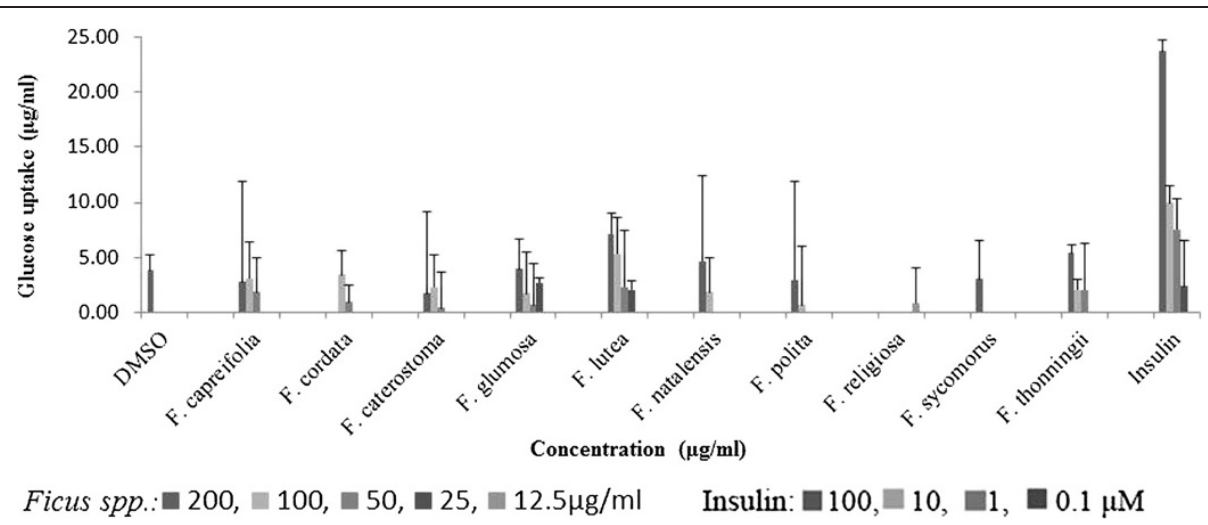

Figure 4 Glucose uptake $(\mu \mathrm{g} / \mathrm{ml}$ ) of rat abdominal primary muscle cultures ( \pm standard error of mean, $n=9$ ) exposed to the acetone extracts of the ten Ficus species and insulin in the present of $1 \mathrm{mM}$ glucose. 


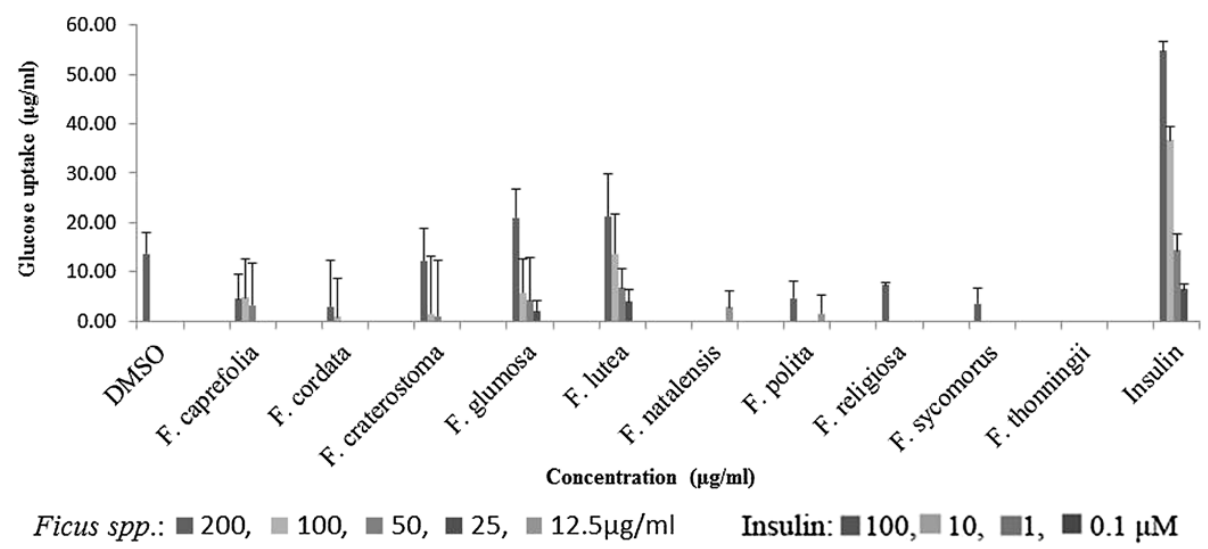

Figure 5 Glucose uptake $(\mu \mathrm{g} / \mathrm{ml})$ of rat epididymal primary fat cell cultures ( \pm standard error of mean, $\mathrm{n}=9$ ) exposed to the acetone extracts of the ten Ficus species and insulin in the present of $1 \mathrm{mM}$ glucose.

\section{Structure elucidation of the isolated compound}

The ${ }^{13} \mathrm{C}$ NMR and DEPT (Distortionless Enhancement by Polarisation Transfer) spectra exhibited signals at $\delta$ 78.7, 66.1 and $28.1 \mathrm{ppm}$ corresponding to carbons C-2, C-3 and C-4 characteristic for a flavan-3-ol skeleton. This was confirmed by the presence of important signals on its ${ }^{1} \mathrm{H}$ NMR spectrum at $\delta 4.87$ (brs, $\mathrm{H}-2$ ), $4.15(m, \mathrm{H}-3), 2.80\left(d d, 4.4,16.8 \mathrm{~Hz}, \mathrm{H}-4_{\mathrm{a}}\right)$ and 2.62 $\left(d d, 3.4,16.6 \mathrm{~Hz}, \mathrm{H}-4_{\mathrm{b}}\right)$ due to protons at positions $\mathrm{C}-2$, $\mathrm{C}-3$ and C-4, respectively. Two sets of aromatic protons were observed on its ${ }^{1} \mathrm{H}$ NMR spectrum: the first set appeared as two doublets at $\delta 5.98(d, 2.2 \mathrm{~Hz}, \mathrm{H}-8)$ and 5.87 (d, $2.2 \mathrm{~Hz}, \mathrm{H}-6)$ due to the ring-A while the second one appeared as AA'BB' system at $\delta 7.28\left(d, 8.4 \mathrm{~Hz}, \mathrm{H}-2^{\prime} / \mathrm{H}-6\right.$ ' $)$ and $6.76\left(d, 8.4 \mathrm{~Hz}, \mathrm{H}-3^{\prime} / \mathrm{H}-5^{\prime}\right)$ corresponding to B-ring. Furthermore, the ${ }^{1} \mathrm{H}$ NMR spectrum also displayed three downfield broad signals between 9.5 and 8.9 ppm assignable to three hydroxyl groups at C-4', C-7 and C-5. The broad singlet multiplicity of proton $\mathrm{H}-2$ was indicative to this proton to be in cis configuration with proton $\mathrm{H}-3$. Moreover, the ${ }^{13} \mathrm{C}$ NMR spectrum exhibited signals at $\delta$ $156.9,156.2,130.4$ and $99.0 \mathrm{ppm}$ corresponding to carbons C-7/C-4', C-5/9, C-1' and C-10, respectively. All these data were in agreement with those published for epiafzelechin (Figure 7) [35]. This compound which was previously reported from Ficus cordata [36] is isolated here for the first time from this species.

\section{Effect of epiafzelechin on glucose uptake in $\mathrm{C} 2 \mathrm{C} 12$ muscle cells}

The effect of epiafzelechin on glucose uptake by the muscle cells, in the presence of insulin was subsequently evaluated. The uptake of glucose by $\mathrm{C} 2 \mathrm{C} 12$ cells treated with epiafzelechin at different concentrations $(15 \mu \mathrm{g} / \mathrm{ml}-250 \mu \mathrm{g} / \mathrm{ml})$ in medium containing two different concentrations of insulin $(1 \mu \mathrm{M}$ and $10 \mu \mathrm{M})$ is presented in Figure 8 . The insulin-mediated glucose uptake of $\mathrm{C} 2 \mathrm{C} 12$ exposed to epiafzelechin at different insulin concentrations of

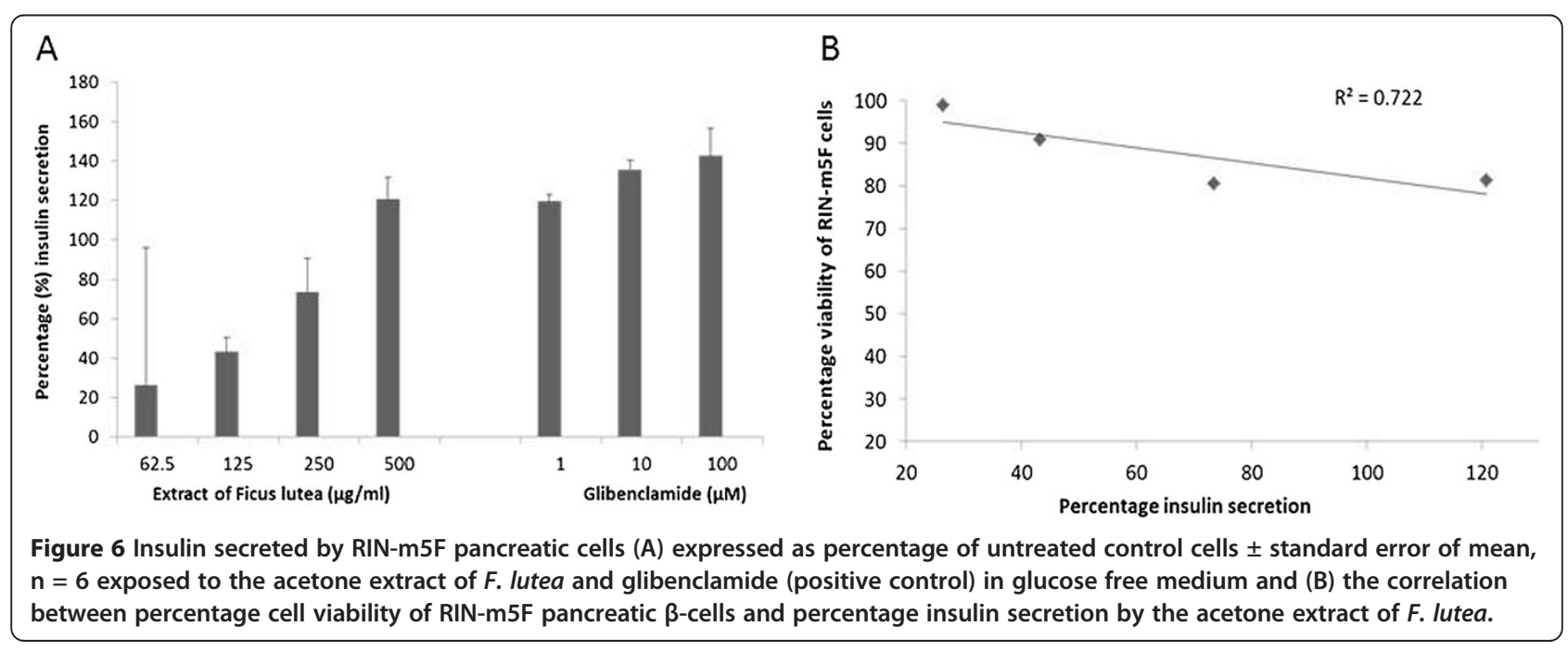




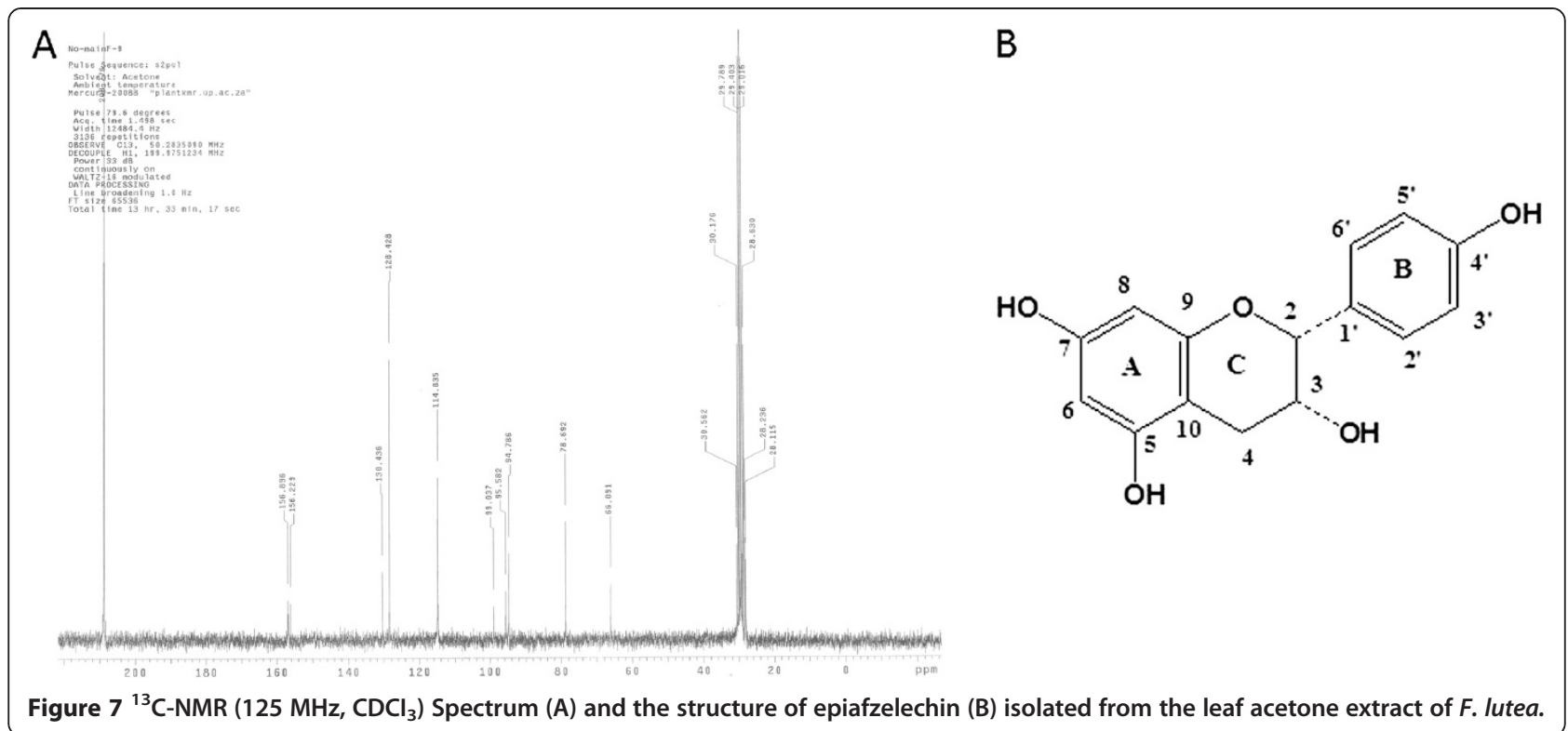

$1 \mu \mathrm{M}$ and $10 \mu \mathrm{M}$ was $22.1 \pm 0.2 \mu \mathrm{g} / \mathrm{ml}(33.2 \pm 0.5 \%)$ and $23.0 \pm 0.7 \mu \mathrm{g} / \mathrm{ml}(34.5 \pm 1.1 \%)$ respectively compared to epiafzelechin alone $[22.2 \pm 0.9 \mu \mathrm{g} / \mathrm{ml}(33.4 \pm 1.8 \%)]$ at the highest epiafzelechin concentration $(250 \mu \mathrm{g} / \mathrm{ml})$. As seen with the acetone extract, epiafzelechin decreased the effectivity of insulin at the lower concentrations.

\section{Effect of epiafzelechin on extracellular glucose concentration of H-4-11-E liver cells}

The effect of epiafzelechin on glucose uptake by the H-4II-E liver cells, in the presence of insulin was evaluated. The uptake of glucose by $\mathrm{C} 2 \mathrm{C} 12$ cells treated with epiafzelechin at different concentrations $(15 \mu \mathrm{g} / \mathrm{ml}-250 \mu \mathrm{g} / \mathrm{ml})$ in medium containing two different concentrations of insulin $(1 \mu \mathrm{M}$ and $10 \mu \mathrm{M})$ is presented in Figure 9. The insulin-mediated glucose uptake in H-4-II-E liver cells exposed to epiafzelechin at different insulin concentrations of $1 \mu \mathrm{M}$ and $10 \mu \mathrm{M}$ was $24.6 \pm 1.1 \mu \mathrm{g} / \mathrm{ml}(36.9 \pm 1.0 \%)$ and $25.3 \pm 0.7 \mu \mathrm{g} / \mathrm{ml}(37.9 \pm 0.9 \%)$ respectively when compared to epiafzelechin alone $[21.6 \pm 1.0 \mu \mathrm{g} / \mathrm{ml}(32.4 \pm 1.5 \%)]$ at the highest concentration $(250 \mu \mathrm{g} / \mathrm{ml})$. As seen with the acetone extract, epiafzelechin decreased the effectivity of insulin at the lower concentrations.

\section{Effect of epiafzelechin on insulin secretion in RIN-m5F pancreatic $\beta$-cells}

Epiafzelechin was evaluated at different concentrations $(62.5 \mu \mathrm{g} / \mathrm{ml}-500 \mu \mathrm{g} / \mathrm{ml})$ for its ability to stimulate insulin secretion in RIN-m5F pancreatic $\beta$-cells and was compared with the untreated control cells. The RIN-m5F pancreatic cells exposed to the epiafzelechin resulted in a dose related increase in insulin secretion (Figure 10A). The insulin secreted significantly $(p<0.001)$ increased from $7.2 \pm 0.21 \mu \mathrm{g} / \mathrm{L}$
$(47.1 \pm 10.2 \%)$ at the concentration of $62.5 \mu \mathrm{g} / \mathrm{ml}$ to $11.2 \pm 0.61 \mu \mathrm{g} / \mathrm{L}(123.9 \pm 19.2 \%)$ at the concentration of $500 \mu \mathrm{g} / \mathrm{ml}$. The correlation coefficient between the viability of RIN-m5F pancreatic $\beta$-cells and insulin secretion by the ethyl acetate fraction of the extract of $F$. lutea $\mathrm{R}^{2}$ was 0.66 (Figure 10B).

\section{Discussion}

Of the ten Ficus spp. evaluated, only F. lutea appeared to have the ability to modulate glucose metabolism. When the glucose uptake ability of the plant extract was compared to insulin in the primary muscle cells, the extract was $33 \%$ as effective. In the hepatoma cell line, the $F$. lutea plant extract was as effective as metformin in decreasing extracellular glucose concentration, by approximately $20 \%$. In the pancreatic secretory assay, the $F$. lutea extract was 4 times greater in its secretory activity than commercial glibenclamide. As a result it would appear that only $F$. lutea has merit in the management of type II diabetes.

The other aim of this study was to ascertain the mechanism by which any of the plants could decreases extracellular glucose concentration. This was facilitated through the use of cell types with different transporter expression criteria for the glucose transport receptors (GLUT), insulin secretion and/or gluconeogenesis. The 3T3-L1 pre-adipocytes predominantly express the GLUT1 glucose transporter over GLUT4 [37]; the differentiated $\mathrm{C} 2 \mathrm{C} 12$ myocytes and the primary cells the GLUT4 transporter and the H-4-II-E hepatoma cells the GLUT2 glucose transporter [38]. While the 3T3-L1 pre-adipocytes can be transformed into adipocytes that express the higher quantities of GLUT4 transporter (5 fold higher), this transformation step was not attempted for this study as we were only 


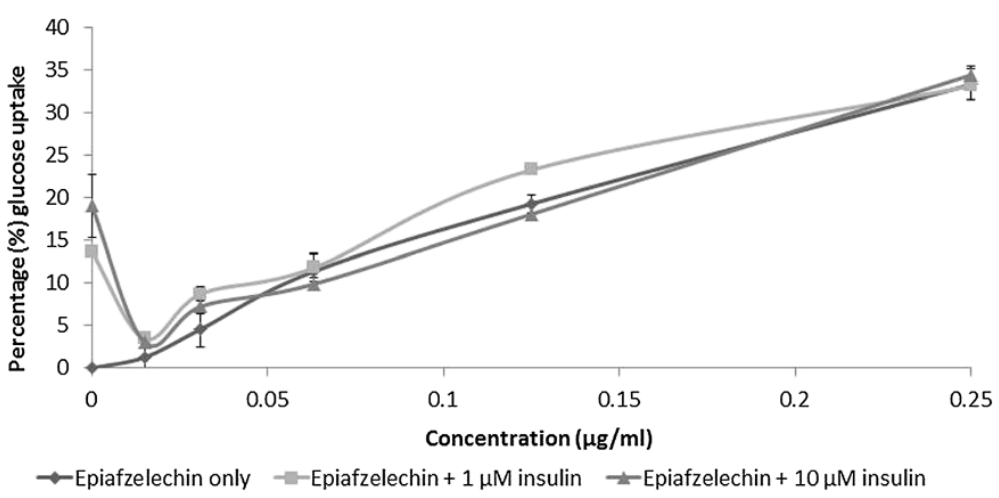

Figure 8 Glucose uptake in $\mathrm{C} 2 \mathrm{C} 12$ muscle cells (expressed as percentage of untreated control cells \pm standard error of mean, $\mathrm{n}=9$ ) exposed to insulin at 1 or $10 \mu \mathrm{M}$, in combination with epiafzelechin.

interested in using the pre-adipocytes as the control in comparison to the other GLUT4 expressing cell lines [39-42]. The hepatoma cell line was also used to study the influence of the extract on gluconeogenesis [43], while the pancreatic cells were used to evaluated insulin secretory activity.

Based upon the poor glucose uptake by the nondifferentiated 3T3-L1 pre-adipocytes and the significantly increasing glucose uptake in the primary muscle cells, primary fat cells, C2C12 muscle and H-4-II-E liver cells, we suspect that the F. lutea extract had its effect by increasing the activity of cell surface glucose transporters either directly or indirectly. With the 3T3-L1 pre-adipocytes being poor in their glucose transporting ability due to low levels of expression of the GLUT4 receptor, this transporter must be considered a possible target site [44]. Furthermore the plant extract did not have the ability to induce differentiation in the pre-adipocytes, indicating the absence of glucocortisteroid capacity. However, with the hepatoma cell lines also showing a decrease in extracellular glucose concentration, decreased gluconeogenesis (with effects being similar to metformin) and/or increased GLUT2 transporter activity are other potential mechanisms. While it is possible that the $F$. lutea plant extract is effective at multiple pathways (GLUT4, GLUT2 and gluconeogenesis), a more plausible explanation is that the extract stimulates the insulin receptor, which on activation would increase GLUT4/2 transporter activity and/or decrease hepatic gluconeogenesis depending on the cell type. However, for the mechanism of action to be fully characterised, further studies are required. One such method could involve evaluating the effects of the $F$. lutea acetone extract on glucose concentrations and/or tyrosine kinase activities, in the presence of an antagonist of the insulin receptor. In studies using the S961 peptide, Sprague Dawley rats showed both a hyperglycaemia and hyperinsulinaemia response when treated with this peptide [45]. If the effect seen by F. lutea acetone extract is indeed mediated via the insulin receptor, one would expect a competitive reduction in the effect achievable or further downstream effects with increasing concentrations of the antagonist added.

To further evaluate whether the effect of the F. lutea extract was being mediated via the insulin tyrosine kinase

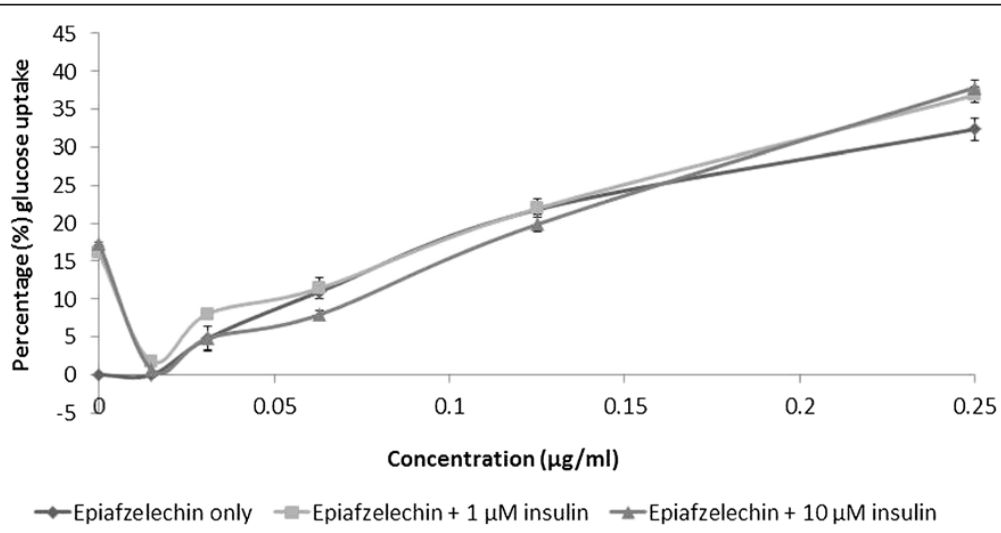

Figure 9 Extracellular glucose concentration of H-4-11-E liver cells (expressed as percentage of untreated control cells \pm standard error of mean, $n=9$ ) exposed to insulin at 1 or $10 \mu \mathrm{M}$, in combination with epiafzelechin. 


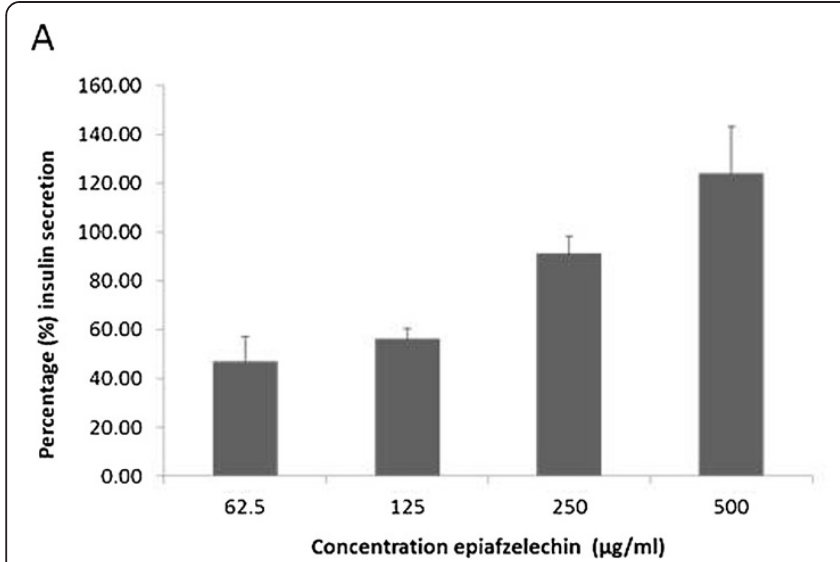

Figure 10 Insulin secreted by RIN-m5F pancreatic cells (A) expressed as percentage of untreated control cells \pm standard error of mean, $n=6$ exposed to epiafzelechin in glucose free medium and (B) the correlation between percentage cell viability of RIN-m5F pancreatic $\beta$-cells and percentage insulin secretion by epiafzelechin.

receptor or related pathways, the effect of insulin alone was compared to that with concurrent F. lutea, or to F. lutea alone. The extract of $F$. lutea failed to further enhance the effect of insulin. For both tissue types an odd profile was attained, as the lower dose of F. lutea appeared to inhibit the response to insulin, while the high dose appeared to be marginally superior to insulin alone, in a manner we consider to be mixed agonistic/ antagonistic activity. The latter response could also explain why the plant extract achieved only a third of the effect of insulin in the primary muscle tissue as it is in essence a partial agonist when acting alone. This result was also similar to that observed with resveratrol, a wine polyphenol which, when used in the absence of insulin, enhanced muscular uptake of glucose, but when added simultaneously to insulin led to a time dependent diminishing of glucose uptake in C1C12 muscle cells [46].

In the final step in elucidating the mechanism of action of $F$. lutea, the influence of the plant extract on insulin secretion was investigated. While not a completely effective means of treating diabetes, the enhanced release of insulin early on in the disease pathogenesis has been known to ameliorate hyperglycaemia. The extracts of $F$. lutea stimulated insulin secretion ( 9 fold) in the RIN-m5F pancreatic cells in comparison to glibenclamide ( 5 fold). While our result thus suggests that the extract of $F$. lutea could possess insulin secretagogue properties, correlation analysis shows an inverse correlation between cell viability and insulin release. This may suggest that the insulin secretory effect seen was an artefact, more likely as a result of the high concentrations inducing cell lyses as opposed to a physiological effect.

One of the compounds we isolated from F. lutea acetone extract was identified as epiafzelechin. As far as it could be established, this is the first study to demonstrate that epiafzelechin has hypoglycaemic activity, as previously shown for other polyphenolic compounds using in vitro muscle and fat cultures [47]. In this study, epiafzelechin enhanced insulin secretory activity of RINm5F pancreatic $\beta$-cells, albeit with correlation with cell toxicity. It also enhanced glucose uptake in $\mathrm{C} 2 \mathrm{C} 12$ muscle cells and decreased extracellular H-4-II-E liver cells glucose concentration in excess of that of the crude extract, most likely due to the same agonistic/antagonistic insulinmimetic mode of action. When insulin and epiafzelechin were added simultaneously to the $\mathrm{C} 2 \mathrm{C} 12$ muscle and $\mathrm{H}-4$-II-E liver cells, there was no significant $(p<0.05)$ change in activity to that in the absence of insulin at the highest concentration. These results are similar to those observed by Ueda et al. [48], where epigallocatechin gallate stimulated a dose dependent increase in glucose uptake of L6 muscle cells with no synergism being present with insulin.

\section{Conclusion}

This study investigated the potential antidiabetic activity of ten Ficus species, focussing on glucose uptake in muscle, fat and liver cells; insulin secretion and safety through cytotoxicity assay. From these traditionally used plant species, only $F$. lutea possessed substantial in vitro activity related to glucose metabolism. When glucose uptake is compared, the plant species was only $33 \%$ as effective as insulin. In comparison to metformin, the plant extract was as effective in inhibiting gluconeogenesis. The plant also appears to lack direct insulin secretory activity. Based on the effect produced in the various cell types, $F$. lutea also appears to be a partial agonist/antagonist of the insulin cell membrane receptor. However, for the true effect of $F$. lutea to be established, in vivo oral rodent efficacy studies in a disease model will be required. The latter is required to determine the biophasic availability of the extract and/or its active constituents and its relationship to efficacy following oral administration. More importantly 
the interaction of the drug with the insulin receptor in the diseased state will also require elucidation.

\section{Competing interests}

The authors declare that they have no competing interests.

\section{Authors' contributions}

$\mathrm{OOO}$ carried out the study and wrote the manuscript; VN and JNE contributed to conception, design, analysis and interpretation of data; LJM assisted with cell culture assays, and LM, JNE and VN assisted with and supervised the manuscript writing. All authors have read and approved the final manuscript.

\section{Acknowledgement}

The National Research Foundation (NRF) of South Africa and the University of Pretoria, provided funding and leaves were collected from the Manie van der Schijff Botanical Garden at the University of Pretoria. Ms. M. Nel of the Manie van der Schijff Garden, Ms. E. van Wyk and Mr. J. Sampson of the HGWJ Schweickerdt Herbarium of the University of Pretoria assisted in the identification, collection and authentication of the plant samples. Ms. A. Venter assisted with tissue culture for the isolation of primary fat cells and with the reviving of established cell lines of muscle, liver and pre-adipocyte. Dr. A. S. Ahmed assisted in running the column chromatography for the isolation of the compound while Prof A. A. Hussein ran the nuclear magnetic resonance (NMR) of the isolated compounds.

\section{Author details}

'Phytomedicine Programme, Department of Paraclinical Sciences, University of Pretoria, Private Bag X04, Onderstepoort, Pretoria 0110, South Africa. ${ }^{2}$ Biomedical Research Centre, Faculty of Veterinary Sciences, University of Pretoria, Onderstepoort, 0110 Pretoria, South Africa. ${ }^{3}$ Permanent address: Federal Institute of Industrial Research Oshodi (FIIRO), Lagos, Nigeria. ${ }^{4}$ Permanent address: Department of Chemistry, University of Dschang, Dschang, Cameroon

Received: 10 December 2013 Accepted: 30 June 2014 Published: 28 July 2014

\section{References}

1. Kamboj VP: Herbal medicine. Curr Sci-Bangalore 2000, 78(1):35-38

2. Hart BL: Biological basis of the behavior of sick animals. Neurosci Biobehav Rev 1988, 12(2):123-137.

3. Cousins D, Huffman MA: Medicinal properties in the diet of gorillas: An ethno- pharmacological evaluation. Afr Stud Monogr 2002, 23:65-89.

4. Reiter $C E$, Gardner TW: Functions of insulin and insulin receptor signaling in retina: possible implications for diabetic retinopathy. Prog Retin Eye Res 2003, 22(4):545-562.

5. Hou JC, Min L, Pessin JE: Insulin granule biogenesis, trafficking and exocytosis. Vitam Horm 2009, 80:473-506.

6. Kaneto H, Katakami N, Kawamori D, Miyatsuka T, Sakamota K, Matsuoka T-A, Matsuhisa $M$, Yamasaki Y: Involvement of oxidative stress in the pathogenesis of diabetes. Antioxid Redox Signal 2007, 9(3):355-366.

7. Jain S, Saraf S: Review on Type 2 diabetes mellitus -its global prevalence and therapeutic strategies. Diab Metab Syndr: Clin Res Rev 2010, 4:48-56.

8. Ducorps M, Ndong W, Jupkwo B, Belmejdoub G, Thiolet C, Mayaudon H, Bauduceau B: Diabetes in Cameroon. Classification difficulties in Africa. Med Trop (Mars) 1996, 56(3):264-270.

9. Venkatesh S, Dayanand Reddy G, Reddy YSR, Sathyavathy D, Madhava Reddy B: Effect of Helicteres isora root extracts on glucose tolerance in glucose-induced hyperglycemic rats. Fitoterapia 2004, 75(3):364-367.

10. Watt JM, Breyer-Brandwijk MG: Medicinal and Poisonous Plants of Southern and Eastern Africa. London: Livingstone Ltd; 1962:773-780.

11. Trivedi P, Hind S, Sharma RC: Preliminary phytochemical and pharmacological studies on Ficus racemosa. J Med Res 1969, 56:1070-1074.

12. Singh RK, Mehta S, Jaiswal D, Rai PK, Watal G: Antidiabetic effect of Ficus bengalensis aerial roots in experimental animals. J Ethnopharmacol 2009, 123:110-114.

13. Perez C, Dominguez E, Ramiro JM, Romero A, Campillo JE, Torres MD: A study on the glycaemic balance in streptozotocin-diabetic rats treated with an aqueous extract of Ficus carica (fig tree) leaves. Phytother Res 1996, 10:82-83.
14. Rao RB, Murugesan T, Sinha S, Saha BP, Pal M, Mandal SC: Glucose lowering efficacy of Ficus racemosa bark extract in normal and alloxan diabetic rats. Phytother Res 2002, 16:590-592.

15. Ghosh R, Sharatchandra KH, Rita S, Thokchom IS: Hypoglycaemic activity of Ficus hispida (bark) in normal and diabetic albino rats. Indian J Pharmacol 2004, 36:222-225.

16. Kumar KA, Maheshwari MU, Sivashanmugam AT, Devi VS, Prasanth NV, Ravi TK: Hypoglycemic effect of Ficus microcarpa leaves (Chinese banyan) on alloxan-induced diabetic rats. J Biol Sci 2007, 7(2):321-326.

17. Pandit R, Phahke A, Jagtap A: Antidiabetic effects of Ficus religiosa extract in streptozotocin-induced diabetic rats. J Ethnopharmacol 2010, 128:462-466.

18. Musabayane $C T$, Gondwe M, Kamadyaapa DR, Chuturgoon AA, Ojewole JAO: Effects of Ficus thonningii (Blume) [Morarceae] stem-bark ethanolic extract on blood glucose, cardiovascular and kidney functions of rats, and on kidney cell lines of the proximal (LLC-PK1) and distal tubules (MDBK). Ren Fail 2007, 29:389-397.

19. Madubunyi II, Onoja SO, Asuzu IU: In vitro antioxidant and in vivo antidiabetic potential of the methanolic extract of Ficus glumosa Del (Moraceae) stem bark in alloxan-induced diabetic mice. Comp Clin Pathol 2012, 21:389-394.

20. Mazumder PM, Farswan M, Parcha V: Hypoglycaemic effect of Ficus arnottiana Miq. bark extracts on streptozotocin induced diabetes in rats. Nat Prod Radiance 2009, 8:478-482.

21. Kar A, Choudhary BK, Bandyopadhyay NG: Comparative evaluation of hypoglycaemic activity of some Indian medicinal plants in alloxan diabetic rats. J Ethnopharmacol 2003, 84:105-108.

22. Adoum OA, Michael BO, Mohammad IS: Phytochemicals and hypoglycaemic effect of methanol stem-bark extract of Ficus sycomorus Linn (Moraceae) on allozan induced diabetic Wistar albino rats. Afr J Biotechnol 2012, 11(17):4095-4097.

23. Adam Z, Khamis S, Ismail A, Hamid M: Ficus deltoidea: A potential alternative medicine for diabetes mellitus. Evid Based Complement Alternat Med 2012. doi: 10.1155/2012/632763.

24. Olaokun OO, McGaw LJ, Eloff JN, Naidoo V: Evaluation of the inhibition of carbohydrate hydrolysing enzymes, antioxidant activity and polyphenolic content of extracts of then African Ficus species (Moraceae) used traditionally to treat diabetes. BMC Complement Altern Med 2013, 13:94.

25. Eloff JN: Conservation of Medicinal Plants: Selecting Medicinal Plants for research and gene banking. Monographs in Systematic Botany from the Missouri Garden. In Conservation of Plants Genes III: Conservation and Utilisation of African Plants, Volume 71. Edited by Adams RP, Adams JE. St. Louis, USA: Missouri Botanical Garden Press; 1998a:209-222.

26. Eloff JN: A sensitive and quick microplate method to determine the minimal inhibitory concentration of plants extracts for bacteria. Planta Med 1998, 64:711-713.

27. Suffness M, Douros J: Drugs of plant origin. Methods Cancer Res 1979, 26:73-126

28. Yin J, Gao Z, Liu D, Liu Z, Ye J: Berberine improves glucose metabolism through induction of glycolysis. Am J Physiol Endocrinol Metab 2008, 294(1):E148-E156.

29. Deutschländer MS, van de Venter M, Roux S, Louw J, Lall N: Hypoglycaemic activity of four plant extracts traditionally used in South Africa for diabetes. J Ethnopharmacol 2009, 124(3):619-624.

30. Gray AM, Flatt PR: Pancreatic and extra-pancreatic effects of the traditional anti-diabetic plant, medicago sativa (lucerne). Br J Nutr 1997 78(2):325-334

31. Rodbell M: The metabolism of isolated fat cells. I. Effects of hormones on glucose metabolism and lipolysis. J Biol Chem 1964, 239:375-380.

32. Martz A, Mookerjee BK, Jung $\mathrm{CH}$ : Insulin and phorbol esters affect the maximum velocity rather than the half-saturation constant of 3-O-methylglucose transport in rat adipocytes. J Biol Chem 1986, 261(29):13606-13609.

33. Persaud SJ, Al-Majed H, Raman A, Jones PM: Gymnema sylvestre stimulates insulin release in vitro by increased membrane permeability. J Endocrinol 1999, 163(2):207-212.

34. Mosmann T: Rapid colorimetric assay for cellular growth and survival: Application to proliferation and cytotoxicity assays. J Immunol Methods 1983, 65(1-2):55-63.

35. Kpegba K, Agbonon A, Petrovic AG, Amouzou E, Gbeassor M, Proni G, Nesnas N: Epiafzelechin from the root bark of cassia sieberiana: Detection by DART mass spectrometry, spectroscopic characterization, and antioxidant properties. J Nat Prod 2010, 74(3):455-459. 
36. Kuete V, Ngameni B, Fotso Simo CC, Tankeu RK, Ngadjui BT, Meyer JJM, Lall $\mathrm{N}$, Kuiate JR: Antimicrobial activity of the crude extract and compounds from Ficus chlamydocarp and Ficus cordata (Moraceae). J Ethnopharmacol 2008, 120(1):17-24

37. Ariga $M$, Nedachi $T$, Katagiri $H$, Kanzaki M: Functional role of sortilin in myogenesis and development of insulin-responsive glucose transport system in C2C12 myocytes. J Biol Chem 2008, 283(15):10208-10220.

38. Scheepers A, Joost HG, Schurmann A: The glucose transporter families SGLT and GLUT: Molecular basis of normal and aberrant function. J Parenter Enter Nutr 2004, 28(5):364-371.

39. Guo X, Liao K: Analysis of gene expression profile during 3T3-L1 preadipocyte differentiation. Gene 2000, 251:45-53.

40. Kaestner KH, Christy RJ, McLenithan JC, Braiterman LT, Cornelius P, Pekala PH, Lane MD: Sequence, tissue distribution, and differential expression of mRNA for a putative insulin-responsive glucose transporter in mouse 3T3-L1 adipocytes. Proc Natl Acad Sci U S A 1989, 86:3150-3154.

41. Garcia de Herreros A, Birnbaum MJ: The acquisition of increased insulin responsive hexose transport in 3T3-L1 adipocytes correlates with expression of a novel transporter gene. J Biol Chem 1989, 264:19994-19999.

42. Richardson JM, Pessin JE: Identification of a skeletal muscle- specific regulatory domain in the rat GLUT 4/muscle-fat gene. J Biol Chem 1993, 268:21021-21027.

43. Saltiel AR, Kahn CR: Insulin signalling and the regulation of glucose and lipid metabolism. Nature 2001, 414(6865):799-806.

44. Liu F, Kim J, Yunsheng L, Xue-qing L, Jing L, Xiaozhuo C: An extract of Lagerstroemia speciosa $\mathrm{L}$. has insulin-like glucose uptake stimulatory and adipocyte differentiation-inhibitory activities in 3TC-L1 cells. J Nutr 2001, 131:2242-2247.

45. Schäffer L, Brand CL, Hansen BF, Ribel U, Shaw AC, Slaaby R, Sturis J: A novel high-affinity peptide antagonist to the insulin receptor. Biochem Biophys Res Commun 2008, 376:380-383.

46. Deng JY, Hsieh PS, Huang JP, Lu LS, Hung LM: Activation of estrogen receptor is crucial for resveratrol-stimulating muscular glucose uptake via both insulin-dependent and -independent pathways. Diabetes 2008, 57(7):1814-1823.

47. Cazarolli LH, Zanatta L, Alberton EH, Figueiredo MS, Folador P, Damazio RG Pizzolatti MG, Silva FR: Flavonoids: Cellular and molecular mechanism of action in glucose homeostasis. Mini Rev Med Chem 2008, 8(10):1032-1038.

48. Ueda M, Nishiumi S, Nagayasu H, Fukuda I, Yoshida K, Ashida H: Epigallocatechin gallate promotes GLUT4 translocation in skeletal muscle. Biochem Biophys Res Commun 2008, 377(1):286-290.

doi:10.1186/1472-6882-14-269

Cite this article as: Olaokun et al:: The potential role of GLUT4

transporters and insulin receptors in the hypoglycaemic activity of Ficus lutea acetone leaf extract. BMC Complementary and Alternative Medicine 2014 14:269

\section{Submit your next manuscript to BioMed Central and take full advantage of:}

- Convenient online submission

- Thorough peer review

- No space constraints or color figure charges

- Immediate publication on acceptance

- Inclusion in PubMed, CAS, Scopus and Google Scholar

- Research which is freely available for redistribution 